\title{
Development Perspectives of Relational Capital in Women-Led Firms
}

\author{
Paoloni M. ${ }^{1}$, Valeri M. ${ }^{2}$, \& Paoloni P. ${ }^{2}$ \\ ${ }^{1}$ Faculty of Economics, Roma Tre University, Italy \\ ${ }^{2}$ Faculty of Economics, Niccolò Cusano University, Italy \\ Correspondence: Valeri M., Faculty of Economics, Niccolò Cusano University, Don Gnocchi Street, 3, Rome, \\ Italy. E-mail: marco.valeri@unicusano.it
}

Received: July 20, 2017

Accepted: August 7, 2017

Online Published: August 12, 2017

doi:10.5539/ijbm.v12n9p66

URL: https://doi.org/10.5539/ijbm.v12n9p66

\begin{abstract}
The purpose of the paper is to analyze the strategic role of relational capital for the achievement of sustainable development in Italian micro and small tourist businesses run by women. The paper focuses on the tourism enterprises because that sector constitute $10 \%$ of the Italian GDP. The qualitative research methodology that has been used is that of case study research (Yin, 2009). Such process consisted in a survey with an ad-hoc questionnaire developed to analyze the distinctive features of a woman-owned micro and small enterprise that can be identified with the CAOS model (Paoloni, 2011). The paper applies the CAOS model examining the personal characteristics of the female entrepreneur (C); the environment in which the in SMEs operates (A); organizational and managerial aspects $(\mathrm{O})$; and the motivations for manage a new business $(\mathrm{S})$. This model is able to link these factors and classify different types of connections, it is possible to identify the kind of existing relations. The paper intends to help address a gap in the existing literature regarding the management and governance of tourism firms run by women. The paper can contribute to improving the competitiveness Italian enterprises studying how women entrepreneurs manage her business.
\end{abstract}

Keywords: Relational capital, entrepreneurship, tourism management, gender, motivation, network, competitive advantage

\section{Introduction}

Having established that micro and small enterprises are key to the development of economic growth and that female micro entrepreneurship is key to these particular types of businesses (David, 2006; Paoloni, 2011), it is interesting to verify how the promotion of relational capital contributes to the success of such economic organizations in terms of support to creativity, talent, production personalisation and personal skills (Hitt, et al., 2002; Klofsten \& Scheele, 2003; Ritchie \& Brindley, 2005; Ireland \& Webb, 2007).

Furthermore, female entrepreneurship is deemed more oriented to a network approach with a greater and significant attention paid to relational aspects (Lerner \& Almor, 2002; Hoang \& Antoncic, 2003; Saxena, 2005; Farr-Wharton \& Brunetto, 2007). Hence, in order to understand how female micro-entrepreneurship considers relational capital essential to its own sustainable development, this paper intends to focus on the implications that facilitate the promotion of policies aiming at the growth of female micro and small entrepreneurship (Yun \& Hyo, 2006).

Consequently, the question of our research is "How does relational capital contribute to the sustainable development of micro and small tourist businesses run by women?"

The tourism industry represents an important economic sector to Italy. As we will explain in the following paragraphs, tourism represents $10 \%$ of the national GDP and $8 \%$ of the European one.

The qualitative research methodology that has been used is that of case study research (Yin, 2009). Such process consisted in a survey with an ad-hoc questionnaire developed to analyze the distinctive features of a woman-owned micro and small enterprise that can be identified with the CAOS model (Paoloni, 2011).

The paper is structured into two sections as follows: the first part focuses on the analysis of the connections between relational capital in women-owned small and micro businesses and the benefits of sustainable development. The second part concentrates on the methodological analysis of some case studies, which highlights the typical features of micro and small businesses run by women, with particular reference to a 
number of aspects such as the personal distinctive traits of the entrepreneur, the environment where the business operates, the organizational and management style and, eventually, the underlying motivation for the business start-up (Kennedy \& Kray, 2015).

\section{Literature Review}

The theoretical framework of this paper is based on a widely structured managerial literature. In particular, we can identify three main research streams: the relational capital of female entrepreneurship, the micro and small businesses in the tourism industry and the analysis of sustainable development in tourism (Vladimirov, 2015; Kask et al., 2016).

According to Costabile (2001), relational capital can be defined as the stock of loyalty and trust that a company needs to strengthen to keep its competitiveness in the course of time. The relational aspect is a hallmark of doing business, because the quality of relationships between entrepreneurs and their customers, suppliers, retailers, manufacturers and other commercial partners, as well as a good reputation on the market and among investors are considered intangible factors that can greatly influence the success of a company (Bergh et al. 2010; Boyd et al., 2010; Lee \& Roh, 2012).

In businesses run by women, relational capital plays a strategic role (Hamzah \& Mat Isa, 2010; Paoloni \& Dumay, 2015; Sansone et al., 2015). According to Gilligan (1982), relations are more frequently found in women-owned businesses throughout all stages of a company life (cooperative approach) for the development of personal and business activities (Aldrich et al., 1989; Argawal \& Malhotra, 2016).

Supporting the development of micro and small businesses, that see women as micro-entrepreneurs, can be considered as an effective economic policy, planned in a strategic way to promote the growth of employment and local development (Farr-Wharton \& Brunetto, 2007).

Micro and small enterprises represent the majority of enterprises within the EU, creating both the largest number of jobs and contributing to development and innovation (David, 2006; Paoloni, 2011; Lazzarotti et al., 2017). Women running these enterprises have different organizational and management approaches (Jardon \& Martos, 2012). For this reason, female micro-entrepreneurship is strongly involved with economic and social policies. Furthermore, whilst researchers have been focusing mainly on the analysis of critical factors which determined the success of social networks in big enterprises (Saxton 1997), they have somehow disregarded the features of micro-enterprises (Human \& Provan, 1997; Sherer, 2003). In particular, they have given little consideration to the role played by women in the network of enterprises, although female businesses currently cover a third of enterprises in Australia and France and nearly half of them in Italy, New Zealand and Spain (Reynolds et al. 2002). The creation of a network in support of the maximization of production, creativity, talent and personal skills is essential for the outliving and development of micro-enterprises (Klofsten \& Scheele, 2003; Ritchie \& Brindley, 2005; Ireland \& Webb, 2007). Former scientific researches suggest that female entrepreneurship is characterized by a network approach, with particular emphasis on the relational aspects (Hoang \& Antoncic, 2003; Farr-Wharton \& Brunetto, 2007; Ozgen \& Baron, 2007).

The sample of women-owned enterprises that are going to be analyzed in this paper operates in the tourism industry of the Italian region of Lazio. The choice of an in-depth examination of this sector is due to its strategic value in the world economy, in terms of contribution to the GDP and job creation. The contribution of tourism to the Italian economy in 2013 amounted to 159.6 billion euros, representing 10.3\% of the national GDP. In Europe, tourism contributed with $8.7 \%$ of the GDP and over $8.5 \%$ of jobs, whilst at world level it contributed with $9.5 \%$ of the GDP and 8.9\% of new jobs (ONT 2014). The economic, social, cultural and educational importance of tourism has been growing at an increasing pace since the second half of the 20th century.

As all social phenomena, the tourist sector has been going through a deep evolution over the years (Valeri \& Baiocco, 2012; Valeri, 2016). In our current complex context of changes, the governance and management of tourist enterprises are responsible for the promotion of sustainability through the development of new tourist products/services that need to be economically advantageous, socially acceptable by the hosting communities and respectful of the local environmental resources (Schianetz et al., 2007).

In the international scientific debate, sustainable development is considered one of the key factors for the successful achievement of enterprises’ competitiveness over time (Valeri, 2016).

Sustainability was defined for the first time in the Brundtland Report (World Commission on Environment and Development 1987). According to it, "tourism activities are sustainable when they develop and are able to keep their vitality in a tourist area for an unlimited time, do not spoil the environment (natural, social and artistic) and do not obstruct or prevent other social and economic activities". This definition can be applied to a large range of 
social and economic situations, whether emerging or undergoing a phase of transformation. The definition itself includes three main essential aspects of sustainable development: economic efficiency, social efficiency and environmental efficiency (Buckley, 2012). According to this definition, tourist enterprises can be considered sustainable when, medium to long term, they define a strategic approach whose aim is supplying tourist services that protect environmental resources and economic aspects and safeguard the identity, the values and the cultural heritage of local populations (Valeri, 2015; 2016).

From this perspective, tourist enterprises that aim at being sustainable - in particular micro and small businesses - must not isolate themselves in the competitive context, but rather become a single knot in the wider network of relations built with all other companies, even of larger size, which are interested in their own survival over time.

Hence, the achievement of sustainable development by tourist enterprises also depends on the relations that each one of them is able to build with the different stakeholders and that aim at achieving a number of common goals such as:

1. Respect and protection of the environment with the objective of minimizing the environmental impact of facilities and activities connected to tourism;

2. Respect and protection of cultural traditions of local population;

3. Engagement of local population in planning innovative and sustainable tourist services;

4. Sharing of the socio-economic benefits deriving from tourism.

The need to join relation networks, as a means of support to micro and small enterprises in the start-up phase, can contribute to improve the effectiveness of policies promoting the engagement of women in the process of economic development.

\section{Methodology}

From a methodology perspective, the research approach is based on the case study research of Yin (2009). The economic context examined is the sector of travel agencies and tour operators of the Italian region of Lazio that, compared to the rest of the other Italian regions, gathers $63 \%$ of all the enterprises of this sector at national level.

More in detail, the branch of travel agencies and tour operators of Lazio comprises 155 micro and small enterprises, of which 58 (38\%) are own exclusively by women and 78 (47\%) managed by women technical directors.

The survey was carried out by submitting an ad-hoc structured questionnaire exclusively to business women running micro and small enterprises, which make up 38\% of the enterprises of this area. The questionnaire was distributed via email and the related addresses were identified both by consulting the web pages of travel agencies and tour operators and the regional Italian Federation of Travel Agencies and Tour Operators.

The survey was launched in May 2015 and the agreed deadline to complete and send back the questionnaire, again by email, was June 2015. The response rate amounted to $62 \%$, that is 34 completed questionnaires and 2 uncompleted ones, all returned by email (58 business women). The questionnaire was structured in an array of questions aiming at analyzing the distinctive factors of female micro and small enterprises (Figure 1). These factors are identifiable in the CAOS model (Paoloni, 2011) and can be summarized in the following items:

1. Personal features of the woman entrepreneur ( C );

2. Environment where the enterprises operates ( A );

3. Organizational aspects and management style $(\mathrm{O})$;

4. Business start-up and motivation ( S )

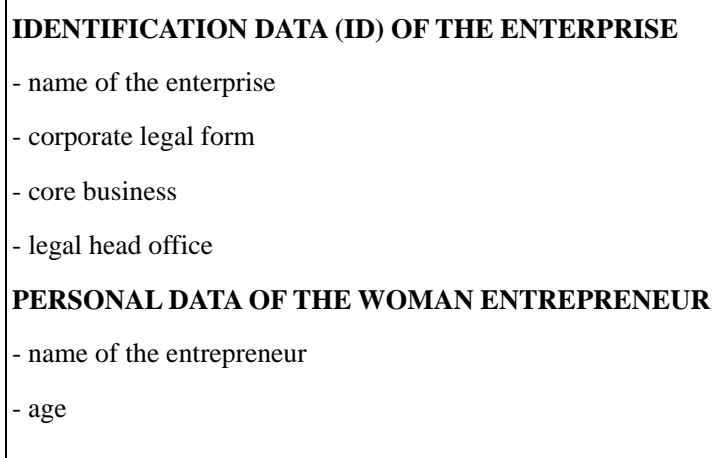




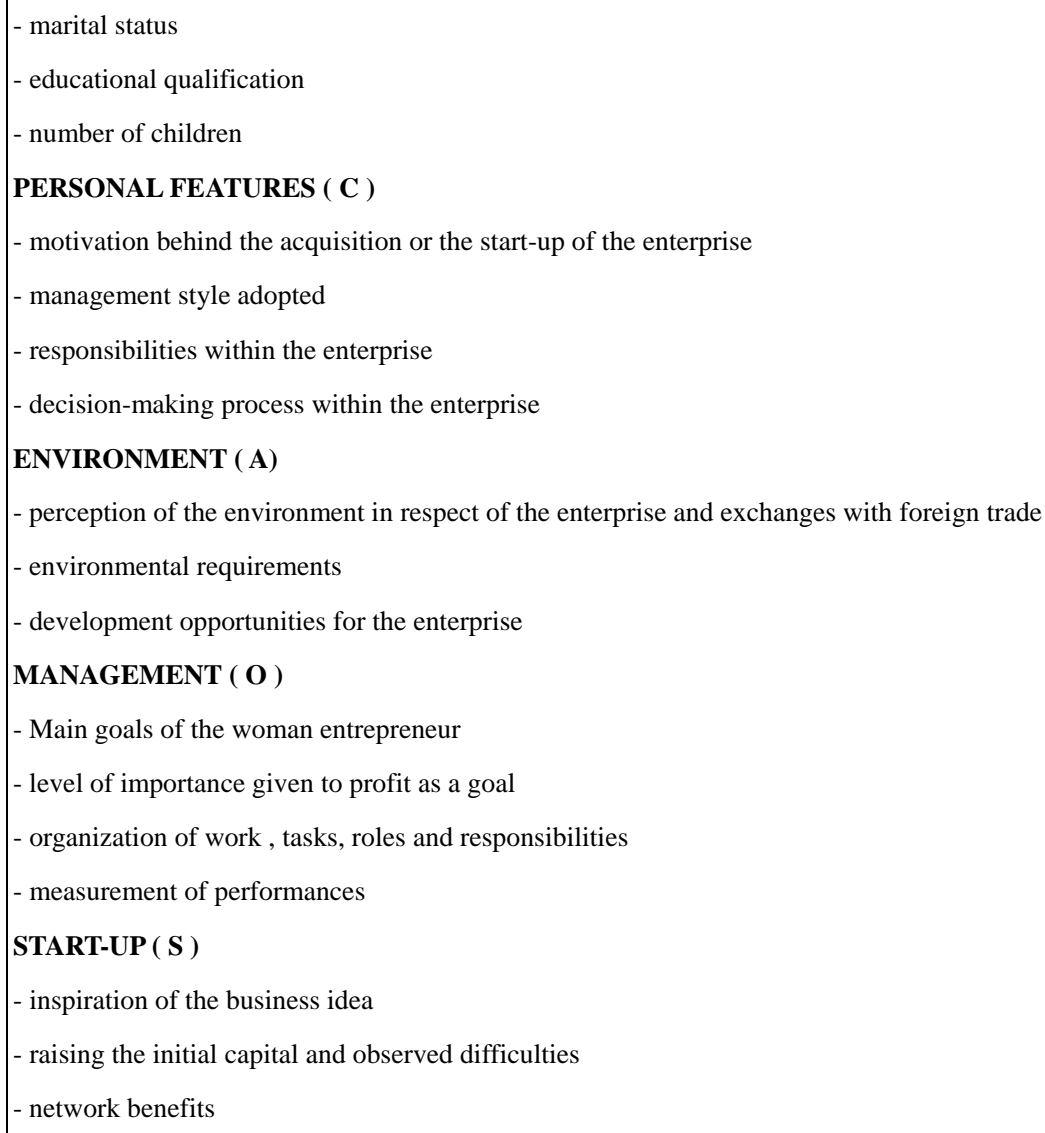

Figure 1. The questionnaire

The analytic aspects discussed in the CAOS model are based on the outcomes of former researches carried out over the past years on enterprises run by women. They can be considered as factors that characterize female entrepreneurship and that define its distinguishing features compared to male entrepreneurship.

\section{Results}

The survey has allowed to analyze the typical factors of a woman-owned micro and small enterprise, with particular attention to the personal characteristics of the entrepreneur (C), to the analysis of the environment where the enterprises operate, to the organizational aspects and management style $(\mathrm{O})$ and eventually, to the analysis of the motivation of the business start-up. In the following paragraphs, these factors are going to be analyzed, according to the responses given by the women interviewed in the survey.

\section{1 "Who Is a Micro Entrepreneur? (C)}

Generally speaking, we define as travel and tourism agencies those enterprises that, either jointly or independently, carry out activities of production, management, mediation of journeys and stays and any other kind of tourist service related to costumer assistance, welcoming and support, with or without direct sale to the public, in compliance with the principles concerning the Consumer Protection as per Italian Legislative Decree No. 206 dated 6 September 2005.

The analysis of the interviews shows a distinction between the role of entrepreneur and the role of technical director, two different professional profiles that do not always coincide. The analyzed enterprises highlight a homogeneity both in terms of size (from 7 to 15 employees with an employment rate amounting to approximately $90 \%$ ) and in terms of legal framework (85\% limited-liability companies and $15 \%$ joint stock companies). On the other hand, there is a lack of homogeneity when we analyze the age of business women (from 40 to 65 years old), their educational qualification and previous work experience.

As far as these latter two aspects are concerned, their diversity is mainly due to the still inadequate training available to the needs of tourism professionals, although Italy represents the nation with the largest number of 
significant archaeological and cultural sites, to a point that it could live only on tourism.

Regardless of the age, the interviewed women consider their activity as:

"A profession encouraging to never give up, be always creative and nurture a strong curiosity. Every day it allows you to live, either first hand or indirectly, the pleasure and the beauty of travelling, knowing that there will always be a destination or a particular itinerary (for example, a tour) that you haven't discovered yet and that you have to find a way to recommend to your customers".

\section{Motivation}

The reasons that have pushed the women entrepreneurs interviewed to start their own activity are connected to motivational variables. These refer to what makes women desire to create their own destiny and have a significant role in the society, such as: emotional needs deriving from a change in their personal life, a challenge to themselves, emancipation and sometimes the necessity to carry on family entrepreneurial activities.

"Self-employment means self-fulfillment and enhancing your intelligence and uniqueness".

"The reason that pushed me to start my own entrepreneurial activity was neither an inner motivation nor a real market opportunity, but rather the impossibility of a career advancement inside small and micro enterprises and the difficulty to endure the hierarchical system typical of a strict and conservative entrepreneurial mindset".

\section{Decision-making process}

The interviews show how the needs of customers, the economic means of families, the chance to collect information on holiday destinations and the process to find new customers have been changing over the years. Likewise, travel agencies and tour operator businesses are increasingly convinced that sustainable development (economic, social and environmental) can influence the achievement of a competitive advantage.

"Travel agencies and tour operators can influence the choices of tourists, the activities of consumers and the development of holiday destinations. Thanks to the peculiarity of their role, they can contribute to the safeguard of environment and culture heritage and can support human and social rights of the destinations they promote".

Although the required standard domain expertise to carry out this type of enterprises is the same as in the past, it is essential to develop new specialized skills to survive in an ever more competitive environment.

To this regard, we refer to marketing and communication expertise. Those who work for small-medium agencies need to be able to take advantage of the ICT network in order to get in touch with an audience much larger than they could do without the help of digital technology.

Certainly, besides the technical side of the job (planning of a journey, management of bookings, ability to solve technical issues as fast as possible, etc.) it is necessary to be flexible when organizing the activities of the company.

Furthermore, a good agent needs to consider the chance to cover particular niches of clients (e.g. people passionate about sports or wine and culinary itineraries), and try to suggest original and specific alternatives. Eventually, it is important to pay due attention to the development of new technologies that represent the essential tools to become ever more competitive over time.

"There has been a sharp decline in the trend of customers turning to travel agencies. Internet is playing an increasing decisive role and therefore travel agencies should use this "tool" at its best and promote it as an operating principle for all their actions. At the same time they should continue to take care of relational aspects with customers, both in presence and online, considering how internet can be the easiest way to reach them and to secure their loyalty".

"It has been more than ten years since internet forcefully penetrated the world of tourism intermediation, creating new vacation selling methodologies. It is undeniable how, in few years and starting from scratch, the On Line Travel Agencies (OLTA) have quickly conquered a significant share of the market, introducing innovative products and functions so as to offer new opportunities to the final customer".

\section{Separation between governance and management}

A separation between the role of entrepreneur and the role of technical director has emerged from the survey, as they are two distinct professional profiles that do not necessarily coincide.

In particular, the defining process of the investigation sample has shown that the branch of travel agencies and tour operators of the Italian region of Lazio consists of 155 micro and small enterprises out of which 58 (38\%) women-owned and 73 (47\%) managed by women technical directors. 
An entrepreneur is an economic operator - natural or legal person- whose task is to control the net asset of the legal entity and, with the aid of the decision-making bodies, to determine the strategic orientation of the enterprise in line with its statutory objectives.” (Cafferata, 2015).

On the other hand, a technical director is the entity responsible for the enterprise management carrying out specialist-technical tasks such as production, travel organization or intermediation and other tourist products. His role is not limited to defining the basic choices of the enterprise's management and organization, but he also oversees its operative divisions.

Hence, a technical director is a professional figure incorporating different characteristics according to the size, organizational model and specialization of the enterprise.

\subsection{The Operative Environment of the Enterprises (A)}

The analysis of the questionnaires has revealed the significant role that associations play in the tourism industry. In this particular case, the Italian Federation of Travel Agencies and Tour Operators represents an important reference point to which tourist operators can address their enquires (e.g. information about how to access the credit market, or to become more familiar with the national and international economic and social context).

"Nowadays joining a trade organization is a controversial choice: some believe it unnecessary, some counter pose it to their self-interest and some others even suspect these organizations hide secret and undefined interests. The truth is that associations represent a great tool born in enterprises to help enterprises. It means participation and development of a healthier democracy. Therefore, it is worth joining the Italian Federation of Travel Agencies and Tour Operators, a qualitative association with many years of experience in this field".

Relations with task and general environment

As the survey's responses show, relations built by women-owned micro and small entrepreneurs with external environment are business related (e.g. connections with customers and suppliers). They can be either formal (such as franchising professionals, consultants, and institutions) or informal (such as friends and families). They both contribute to a sustainable development of the tourism industry.

"We believe that the achievement of sustainability also implies the management of the network of relations built over time with suppliers of tourist services. In our specific entrepreneurial reality, the tourist destinations that we have been promoting to our customers in these late years, have increased their sustainability after having set a number of sustainability standards (economic, environmental and social) with accommodation and transport organizations for the management of cultural and recreational outdoor activities (e.g. trekking and diving)".

\section{Environmental needs}

The interviewed women entrepreneurs have declared that, before starting their own activity, they had run a market analysis to investigate the potentiality of their business. Such an analysis has not been restricted to the planning stage, but it has continued steadily over the years in order to evaluate the opportunities of development and differentiation in other markets. Clearly, the aim of these studies is to identify the emerging needs of tourists, who keep requiring ever more customized journeys. One of the priority requirements expressed by the interviewees is to understand the evolution and the potentiality of the Web and ITC (Information and Communications Technology) within the tourism industry, both domestic and international.

"The analysis of the impact of Internet and ICT is essential to meet the strong requirements of tourist operators to be informed on positive and/or negative effects of these new technologies and to find the best way to guide tourism industry's changes in a reactive and proactive perspective so as to avoid feeling under pressure".

For quite some time now, the evolution of technologies has been having both positive and negative effects on the mode of operation of the tourist system:

a) Increasingly available information has determined a tougher competition between products and tourist destinations,

b) Having become more and more mature, tourists tend to arrange by themselves their holidays (dynamic packaging) according to their travel needs,

c) The importance of transactions through travel agencies is bound to decrease because of the large number of available online holiday packages,

d) The evolution of Internet related technologies has started to change the strategic role of domestic and international tourist players, creating new requirements for more specialized skills,

e) The possibility to buy products online has started to encourage last-minute purchases and, therefore 
f) Tourists have become increasingly conscious of the security issues of online transactions.

"Being aware of this long announced technological and "mental" revolution, as tourist operators we have to deal with customers who are becoming increasingly "digital friendly" and who are looking for tourist solutions more and more suitable to their needs. They indeed represent the large Internet community that in Italy has an annual rate of growth amounting to approximately 11\%".

\section{Development opportunities}

The necessity to diversify the entrepreneurial activity is significant to $25 \%$ of the interviewees, who aim to reach international markets offering better opportunities, although still unknown. On the other hand, $75 \%$ of the interviewed entrepreneurs considers it more advantageous to stick to traditional markets, as they cannot afford new competitive challenges.

"Promoting "sustainable" travels also means using local accommodation, facilities and public transportation, so that money can be spent locally. Depending on the case, overnight stays will be arranged at facilities as environment-friendly as possible, such as infrastructures provided by the organizations hosting the visits, family run hotels and/or local bed-and-breakfasts. As far as transportation is concerned, it is recommended the use of locally rented cars or vans, taxicabs, public buses, trains, ferries and planes for domestic flights".

\subsection{How does Micro and Small Entrepreneur Manage the Enterprise?” $(O)$}

Despite the very limited size of the enterprises under examination, it was also worth examining the type of relations among owners, managers and employees. The survey has shown how women entrepreneurs are more inclined to adopt a participatory management approach rather than a strict and authoritative style.

"Creating and maintaining such a working environment, where participation prevails over authority, assumes that there is a structured organization specifically devoted and oriented to facilitate the development of tourist packages that fulfill environmental and social sustainability standards".

"It is important to activate an incentive system encouraging creativity and autonomy and rewarding human resources who participate in the development of innovative tourist packages. Only in this way, we will be able to promote the local intangible cultural heritage of the hosting tourist destinations and to engage small enterprises, whether local or not, which might represent as well a financial source, improving the quality of the accommodation service and of tourist services in general".

\section{Objectives}

The main objective of the examined enterprises is to supply a quality service able to meet customers' needs. This can be achieved by activating a network of relations comprising all the stakeholders with whom enterprises interact.

Cooperation among micro and small enterprises can represent a key choice for their development and growth. The implementation of cooperation strategies through enterprise networks is considered as an alternative to the internal growth allowing smaller enterprises to survive and face dynamic and hyper-competitive contexts (Runyan et al., 2006).

The survey shows that $68 \%$ of women entrepreneurs considers profit the fundamental drive to start up an enterprise. On the other hand, 32\% of them leaves profit out of the motivations, pointing out that the main reasons are personal fulfillment, self-esteem, personal satisfaction, self-sufficiency, personal challenge.

"Being passionate comes first. Everyday travel agents work with their customers' dreams, their vacations. Not only do they travel "physically", but they travel "mentally": they are always on vacation, obviously together with tourists. Vacations become stimulating when they have the chance to promote travel destinations where environment is respected and safeguarded by focusing on the minimization of the environmental impact of facilities and activities linked to tourism, which encourage the active participation of local populations and respect and protect their traditional culture".

\section{Measurement of performances}

Women entrepreneurs try to measure on a regular basis the performances of their economic business, as shown in the analysis (Dorta-Afonso and Hernández-Martín, 2015). It is now standard practice to hand out assessment questionnaires to customers, which help evaluate the satisfaction rate for both the assistance received in the travel agency and throughout the entire journey. Although at the beginning word-of-mouth represented an important tool to gain new customers, with time it became clear that it was necessary to take advantage of the opportunities arisen from adhering to trade associations that, thanks to social networks, help tourist operators 
connect to potential customers.

\subsection{How does a Business Enterprise Start? (S)}

$72 \%$ of the interviewees said that they have taken over the family tourist business. The remaining $28 \%$ said that they have started up their own business, with no cases of second generation. In this latter case, we can easily understand all the difficulties met in developing the business idea, in the start-up phase and finally in the management of the actual economic business.

\section{The business idea}

It was not easy for the interviewed women entrepreneurs to answer the question about the origin of their business idea. $12 \%$ said it was conceived by chance, $72 \%$ continued a family tradition and $16 \%$ wanted to capitalize former professional experience.

"In order to make a travel agency business idea successful, it is necessary to have a good tourist and geographic culture and an ability to detect customers' needs and expectations. Furthermore, you need to be able to manage the different channels of communication for both the promotion and the organization of work, being able to manage the relationships with customers, keeping abreast with main political and economic events, knowing and respecting the national and regional tourist laws and regulations, interacting with suppliers and, above all, being familiar with foreign languages".

Initial economic investment and first difficulties

The interviews have shown that the main difficulties met in the development of the economic activity are to be ascribed to the high degree of difficulty to access to credit from financial institutions. Although these enterprises are travel agencies and tour operators, that means that they do not require the purchase of industrial plants and machinery, however the development of this business requests renting a place where carrying out the activities and, above all, purchasing some expensive software to manage bookings and national and international invoicing.

"The initial investment is limited if compared to that of other activities (it costs less to start up a travel agency than a clothing business) and, not needing a storehouse, even management costs are moderate".

\section{Discussion}

The survey has allowed to highlight the typical key factors of a woman-owned micro and small enterprise, starting from the analysis of the personal features of the entrepreneur (C), the environment in which the enterprise operates (A), the organizational aspects and management style (O), up to the business start-up and its motivation (S). This analysis enables us to verify whether the valorization of relational capital contributes to the achievement of sustainable development of female micro and small enterprises operating in the tourism industry.

One of the most significant aspect that has emerged from the survey is the way women entrepreneurs do business, which is strictly linked to their ability to create a network of relations with all stakeholders and, above all, to make it work seamlessly (Scott, 1986). Well-structured networks can improve management efficiency and lower mortality rate of micro and small businesses during the start-up process. These relations are often commercial (e.g. relations with customers and suppliers). Sometimes they can be formal (e.g. franchising professionals, consultants, institutions), but in most cases they are informal, due to the need of balancing work and family, and getting relatives and friends involved in the network..

The complexity of the environment, either general or specific, and the growing pressure of competition stimulate the creation and the development of inter-organizational relations. These allow entrepreneurs to gain and exploit new resources/knowledge on one side, while decreasing the environmental uncertainty on the other.

Especially for the micro and small enterprises under examination, cooperation through networks is considered relevant and decisive for their durability over time. It is therefore essential for them to adopt networks as an organizational model, if they intend to defend themselves against strong competitive pressures and to overcome the lack of knowledge/resources that often marks them.

Networks are developed not only to avoid threats but also to enhance the competitive position of enterprises, for instance to grasp new market opportunities and beat stronger competitors.

This allows enterprises to meet those market challenges that could not be tackled by counting only on their own limited resources.

Especially in the examined tourist segment, networks have been created to improve tourist planning and promotion and to develop a product/service suitable to fulfill the needs of increasingly demanding customers. 
Mutual trust amongst the different actors is an essential requirement to create and develop a network of relations. Trust, in effect, plays a significant role in facilitating relations amongst partners.

\section{Conclusions and Limits}

This paper is an opportunity for reflection on the competitive potential of micro and small enterprises operating in the tourism industry.

The purpose of the paper is to analyze the strategic role of relational capital for the achievement of sustainable development in Italian micro and small tourist businesses run by women.

Reports in the literature indicate that such enterprises can be competitive if able to create and guarantee over time a better tourist experience, compared to that offered by other territories and by competitors.

We can then conclude by affirming that competitiveness presumes sustainability. Achieving sustainable development increasingly demands an ever more structured, balanced and coherent set of economic, legislative, technical and financial measures.

Therefore, while the competitive advantage of a tourist enterprise depends on resources available and on the features of the network of relations, it is fundamental to be capable to use them correctly and to improve the relations in place over the course of time.

However, this requires a greater attention from Institutions that, in a competitive complicated context such as the current one, should promote the development of business activities run by women entrepreneurs with actions aimed at sustaining their growth. Female micro and small enterprises represent an important development and innovation drive to Italy.

The restricted number of companies surveyed (34) and the confined area examined (Lazio Region) represent a limit to the present research. From a future research perspective, it is therefore desirable to complete this work with an additional analysis of all micro and small tourist businesses run by women entrepreneurs operating in all Italian regions, in order to find new opportunities, raise critical aspects and, above all, highlight appropriate actions for the territorial development.

\section{References}

Aldrich, H., Reese, P. R., \& Dubini, P. (1989). Women on the verge of a breakthrough: networking among entrepreneurs in the United States and Italy. Entrepreneurship \& Regional Development, 1(4), 339-356. http://dx.doi.org/10.1080/08985628900000029

Argawal, R., \& Malhotra, G. (2016). Women and access to ICT: A case study of India. African Journal of Business Management, 10(11), 288-297. http://dx.doi.org/10.5897/AJBM2013.7306

Bergh, D. D., Ketchen, D. J., Boyd, B. K., \& Bergh, J. (2010). New frontiers of the reputation - Performance relationship: insights from multiple theories. Journal of Management, 36(3), 620-632. https://doi.org/10.1177/0149206309355320

Boyd, B. K., Bergh, D. D., \& Ketchen, D. J. (2010). Reconsidering the reputation - performance relationship: a resource-based view. Journal of Management, 36(3), 588-609. https://doi.org/10.1177/0149206308328507

Buckley, R. (2012). Sustainable tourism: Research and reality. Annals of Tourism Research, 39(2), 528-546. https://doi.org/10.1016/j.annals.2012.02.003

Costabile, M. (2001). Il capitale relazionale. Milano: McGraw-Hill.

David, P. (2006). Il valore della differenza. La risorsa femminile nella creazione di impresa. Roma: Carrocci.

Dorta-Afonso, D., \& Hernández-Martín, R. (2015). Subnational tourism competitiveness performance. The Canary Islands vs. the German Länder. European Journal of Tourism Research, 10, 51-63.

Farr-Wharton, R., \& Brunetto, Y. (2007). Women entrepreneurs, opportunity recognition and government-sponsored business networks: a social capital perspective. Women in Management Review, 22(3), 187-207. https://doi.org/10.1108/09649420710743653

Gilligan, C. (1982). In a Different Voice: Psychological Theory and Women's Development. Harvard University Press: Cambridge, MA.

Grondin, D., \& Schaefer, N. (1995). Differences in the export activities of female-and male-owned small and medium-sized enterprises. Women in Management Review, 10(8), 4-10. https://doi.org/10.1108/09649429510102099 
Hamzah N., \& Mat Isa, R. (2010). Intellectual and Social Capitals Development A Case in Malaysian's ICT Companies. International Journal of Business and Management, 5(1), 54-61. http://dx.doi.org/10.5539/ijbm.v5n1p53

Hitt, M., Ho-Uk, L., \& Yucel, E. (2002). The Importance of Social Capital to the Management of Multinational Enterprises: Relational Networks among Asian and Western Firms. Asia Pacific Journal of Management, 19(2/3), 353-373.

Hoang, H., \& Antoncic, B. (2003). Network-based research in entrepreneurship: a critical review Journal of Business Venturing, 18(2), 165-187. https://doi.org/10.1016/S0883-9026(02)00081-2

Human, S. E., \& Provan, K. G. (1997). An emergent theory of structure and outcomes in small-firm strategic manufacturing networks, Academy of Management Journal, 40(2), 368-403. http://dx.doi.org/10.2307/256887.

Ireland, D. R., \& Webb, J. W. (2007). Strategic entrepreneurship: creating competitive advantage through streams of innovation. Business Horizons, 50(1), 49-59. https://doi.org/10.1016/j.bushor.2006.06.002

Lazzarotti, V., Manzini, R., Nosella, A. \& Pellegrini, L. (2017). Innovation ambidexterity of open firms. The role of internal relational social capital. Technology Analysis \& Strategic Management, 29(1), 105-118. http://dx.doi.org/10.1080/09537325.2016.1210119

Lerner M., \& Almor, T. (2002). Relationships among strategic capabilities and the performance of women-owned small ventures. Journal of Small Business Management, 40(2), 109-125. http://dx.doi.org/10.1111/1540-627X.00044

Jardon, C. M., \& Martos, M. S. (2012). Intellectual capital as competitive advantage in emerging clusters in Latin America. Journal of Intellectual Capital, 13(4), 462-481. https://doi.org/10.1108/14691931211276098

Kask, S., Kull, T., \& Orru, K. (2016). Understanding of sustainable tourism among Russian tourism managers. European Journal of Tourism Research, 14, 101-105.

Kennedy, J., \& Kray, L. (2015). A pawn in someone else's game?: The cognitive, motivational, and paradigmatic barriers to women's excelling in negotiation. Research in Organizational Behavior, 35, 3-28. https://doi.org/10.1016/j.riob.2015.09.002

Klofsten, M., \& Scheele, J. (2003). Innovation and small enterprises in the Third World. International Small Business Journal, 21(3), 354-357.

Lee, J., \& Roh, J. J. (2012). Revisiting corporate reputation and firm performance link. Benchmarking: An International Journal, 19(4/5), 649-664. https://doi.org/10.1108/14635771211258061

Ozgen, E., \& Baron, R. A. (2007). Social sources of information in opportunity recognition: effects of mentors, industry networks, and professional forums. Journal of business venturing, 22(2), 174-192. https://doi.org/10.1016/j.jbusvent.2005.12.001

Paoloni, P., \& Dumay, J. (2015). The relational capital of micro-enterprises run by women: the startup phase. VINE, 45(2), 172-197. https://doi.org/10.1108/VINE-01-2014-0003

Paoloni, P. (2011). La dimensione relazionale delle imprese femminili. Milano: Franco Angeli.

Reynolds, P. D., Camp, S., Bygrave, W., Autio, E., \& Hay, M. (2002). Global Entrepreneurship Monitor: 2001 Summary Report, Kauffman Centre for Entrepreneurship. Wellesley, MA.

Ritchie, B., \& Brindley, C. (2005). Cultural determinants of competitiveness within SMEs. Journal of Small Business and Enterprise Development, 12(1), 104-119. https://doi.org/10.1108/14626000510579671

Runyan., R. C., Huddleston, P., \& Swinney, J. (2006). Entrepreneurial orientation and social capital as small firm strategies: A study of gender differences from a resource-based view. The International Entrepreneurship and Management Journal, 2(4), 455-475. https://doi.org/10.1007/s11365-006-0010-3

Sansone, M., Moretta Tartaglione, A., \& Bruni, R. (2015). Enterprise-Place Relationship and Value Co-Creation: Advance in Research. International Journal of Business and Management, 10(1), 50-61. http://dx.doi.org/10.5539/ijbm.v10n1p50

Saxena, G. (2005). Relationships, networks and the learning regions. Tourism Management, 26(2), 277-289. http://dx.doi.org/10.1016/j.tourman.2003.11.013

Saxton, T. (1997). The effects of partner and relationship characteristics on alliance outcomes. Academy of Management Journal, 40(2), 443-461. http://dx.doi.org/10.2307/256890. 
Schianetz, K., Kavanagh, L., \& Lockington, D. (2007). The Learning Tourism Destination: The potential of a learning organization approach for improving the sustainability of tourism destinations. Tourism Management, 28(6), 1485-1496. https://doi.org/10.1016/j.tourman.2007.01.012

Scott, C. E. (1986). Why more women are becoming entrepreneurs. Journal of Small Business Management, 24(4), 37-44.

Sherer, S. A. (2003). Critical success factors for manufacturing networks as perceived by network coordinators. Journal of Small Business Management, 41(4), 325-345. http://dx.doi.org/10.1111/1540-627X.00086

Valeri, M. (2016). Networking and cooperation practices in the Italian tourism business. Journal of Tourism, Heritage \& Services Marketing, 2(1), 30-35. http://doi.org/10.5281/zenodo.376333.

Valeri, M. (2015). Sustainability development and competitiveness of Rome as a tourist destination. Tourism and Hospitality Management, 21(2), 203 - 218. http://dx.doi.org/10.20867/thm.21.2.7

Valeri, M., \& Baiocco, S. (2012). The integration of a Swedish minority in the hotel business culture: the case study Riva del Sole. Tourism Review, 67(1), 51-60. http://dx.doi.org/10.1108/16605371211216378.

Vladimirov, Z. (2015). Factors for the e-business adoption by small tourism firms and the role of shadow economic practices. European Journal of Tourism Research, 10, 5-34.

World Commission on Environment and Development (1987). Our common future-The Brundtland report, Oxford University Press, New York.

Yin, R. K. (2009). Case study research: Design and methods (3rd ed.) Thousand Oaks, Calif: Sage Publications.

Yun Ji M., \& Hyo, G. K. (2006). A Model for the Value of Intellectual Capital. Canadian Journal of Administrative Sciences, 23(3), 253-269. http://dx.doi.org/10.1111/j.1936-4490.2006.tb00630.x

\section{Copyrights}

Copyright for this article is retained by the author(s), with first publication rights granted to the journal.

This is an open-access article distributed under the terms and conditions of the Creative Commons Attribution license (http://creativecommons.org/licenses/by/4.0/). 